\title{
Watermelon general and specific combining ability
}

\author{
Tiago Lima do Nascimento'* Flávio de França Souza², \\ Rita de Cassia Souza Dias², Edson Ferreira da Silva'
}

'Rural Federal University of Pernambuco, Recife, Brazil

${ }^{2}$ Brazilian Agricultural Research Corporation, Petrolina, Brazi

*Corresponding author, e-mail: tiago_lim.a@hotmail.com

\begin{abstract}
The combining ability of six watermelon genotypes was estimated in a diallel cross scheme (6x6), including genotypes JNY (1), 'ORA' (2), 'KOD' (3), 'SOL' (4), 'CHG' (5), 'PEA' (6) and all possible hybrids between them. A randomized complete block design (RCB) was used, with 36 treatments, three blocks, and plots with five plants. The following traits were evaluated: days before female flower anthesis, main branch length, fruit mass, number of fruits per plant, yield, fruit length, fruit width, pulp firmness, soluble solids content, average rind thickness, seed length, seed width, and seed mass. The data obtained were submitted to analysis of variance, and a diallel analysis was performed according to Griffing's experimental method I. According to the general combining ability estimates obtained, genotypes 'KOD' (3) and 'JNY' (1) were the most likely ones to produce hybrids with smaller-sized fruits and smaller seeds. The reciprocal effects confirmed that the results indicate that these genotypes should be used as pollen donors and pollen recipients, respectively. On the other hand, genotypes 'ORA' (2) and 'CHG' (5) can be used for the commercial exploitation of sliced watermelons. According to the specific combining ability estimates obtained, the combinations 'ORA' (2) X 'PEA' (6), 'ORA' (2) X 'JNY' (1), 'CHG' (5) x 'KOD' (3), 'PEA' (6) x 'KOD' (3), and 'CHG' (5) x 'SOL' (4) stood out as being the genotypes most likely to produce the smallest fruits and smallest seeds.
\end{abstract}

Keywords: Diallel analysis, Citrullus lanatus, plant breeding

\section{Introduction}

Watermelon [Citrullus lanatus (thunb.)

Matsum \& Nakai] has great social and economic importance (RAMOS et al., 2012) owing to its wide use in the Brazilian diet, its nutritional properties, easy consumption and low caloric content (Gama \& VIZA, 2008). The 2015 Brazilian watermelon production was 2,119,599 $\mathrm{t}$, with 97,910 ha of cultivated crops (IBGE, 2016). However, such production can be even higher if new genotypes with different fruit patterns are developed in order to meet the new market requirements (Souza, 2008).

The market demand in Brazil is for smaller fruits for easier transportation, domestic storage, targeted especially at families with few members. However, the main cultivars commercialized in the country were developed from 'Crimson Sweet', a genotype with fruit mass greater than $10 \mathrm{~kg}$ (Nascimento et al., 2018), which provides consumers with fewer options for choice. This demand can be met with the development of new commercial genotypes in breeding programs, using the genetic diversity of local varieties and Germplasm Active Banks (GABs).

Important watermelon diversity sources of local varieties maintained in traditional agriculture were reported by Nantoumé et al. (2012) and Nantoumé et al. (2013). In terms of Germplasm Active Banks (GABs), accessions Received: 21 June 2017 Accepted: 21 November 2018 
with important genetic diversity sources were reported by Adjoumanl et al. (2016), Gama et al. (2013) and Gbotto et al. (2016). However, to use such genetic resources, a better understanding of genotypes is necessary as regards their main agronomic traits available for the attainment of greater efficiency in the choice of parents and the use of the most adequate breeding techniques (Souza et al. 2013).

In watermelon crops, the ability to combine potential parents is one of the most important information, which also allows identifying the most suitable parents for the transmission of desirable characters in commercial hybrids.

Studies on the combining ability of different crops have been carried out, such as beans (Rocha et al., 2014), onion (Santos et al., 2015), maize (Barreto et al., 2012), carrot (Carvalho et al., 2014), among others, which have generated important information for the development of commercial hybrids. As regards watermelon crops specifically, studies were conducted by Adjoumani et al. (2016), Singh et al. (2009), Piovesan (2012), Souza et al. (2013) and Sapovadiya et al. (2014).

In view of the above, this paper aimed to estimate the combining ability of watermelon genotypes in order to identify promising parents for the development of new commercial cultivars with smaller-sized fruits and smaller seeds in breeding programs.

\section{Material and methods}

The hybrid seeds of the study were obtained from the experimental field of Embrapa Semiárido, located in the irrigated perimeter of the Bebedouro irrigation project, in the municipality of Petrolina, PE, Brazil (907'56" S/40 $17^{\prime} 59.57^{\prime \prime}$ W), between January and March 2015, using controlled hand pollination (CHP) according to the method used by Gama et al. (2015).

The six parents 'JNY' (1), 'ORA' (2), 'KOD' (3), 'SOL' (4), 'CHG' (5) and 'PEA' (6), the $15 F_{1}$ hybrids, interpopulations and their reciprocals, originated from all possible combinations between parents (Table 1), were evaluated in the same experimental field of Embrapa Semiárido between April and August 2016.

Table 1. Origin and main traits of the watermelon genotypes under analysis

\begin{tabular}{|c|c|c|}
\hline Genotypes & Origin & Main traits \\
\hline 'JNY' (1) & Netherlands - NED & $\begin{array}{l}\text { Early cycle, prolific, round fruits, striped, red pulp, high } \\
\text { soluble solids content, and very small seeds. }\end{array}$ \\
\hline 'ORA' (2) & United States - EUA & $\begin{array}{l}\text { Late cycle, little prolific, round fruits, striped, orange pulp, } \\
\text { high soluble solids content, and large seeds. }\end{array}$ \\
\hline 'KOD' (3) & Japan - JPN & $\begin{array}{l}\text { Early cycle, prolific, round fruits, striped, light yellow pulp, } \\
\text { high soluble solids content, and small seeds. }\end{array}$ \\
\hline 'SOL' (4) & Brazil - BRA & $\begin{array}{l}\text { Very early cycle, prolific, round fruits, striped, canary-yellow } \\
\text { pulp, high soluble solids content, and medium-size seeds. }\end{array}$ \\
\hline 'CHG' (5) & United States - EUA & $\begin{array}{l}\text { Late cycle, little prolific, long fruits, no stripes, rosy pulp, high } \\
\text { soluble solids content, and large seeds. }\end{array}$ \\
\hline 'PEA' (6) & United States - EUA & $\begin{array}{l}\text { Late cycle, little prolific, oblong fruits, no stripes, medium } \\
\text { red pulp, high soluble solids content, and medium-size } \\
\text { seeds. }\end{array}$ \\
\hline
\end{tabular}

The seeds were sown in polyethylene trays on May 9, 2016, and the seedlings were transplanted to the field 15 days after sowing. A randomized block design (RBD) with three replications was used. Each plot consisted of a row with five plants, and spaces of $2.5 \mathrm{~m}$ between rows and $1.0 \mathrm{~m}$ between plants. Drip irrigation was used, and daily water supply was applied according to the crop needs and climatic conditions, monitored by a weather station located near the experimental area.

Fertilization drew on soil analysis and as recommended by Mendes et al. (2010), with a basal fertilizer containing $30 \mathrm{~kg} \mathrm{ha}^{-1}$ of $\mathrm{N}, 80 \mathrm{~kg} \mathrm{ha}^{-1}$ of $\mathrm{P}_{2} \mathrm{O}_{5^{\prime}}$ and $30 \mathrm{~kg} \mathrm{ha}^{-1}$ of $\mathrm{K}_{2} \mathrm{O}$, plus $15 \mathrm{~kg} \mathrm{ha}^{-1}$ of zinc sulphate and $10 \mathrm{~kg} \mathrm{ha}^{-1}$ of copper sulphate. Top-dressing fertilizer was applied via irrigation water, using $50 \mathrm{~kg} \mathrm{ha}^{-1}$ of $\mathrm{N}$ of calcium nitrate and 
$40 \mathrm{~kg} \mathrm{ha}^{-1}$ of $\mathrm{K}_{2} \mathrm{O}$ (potassium sulphate), applied up to 50 and 60 days after sowing, respectively. Phytosanitary treatments were carried out by applying agrochemicals suitable for the crop and registered by the Brazilian Ministry of Agriculture, Livestock, and Supply, and weed management was performed by hand weeding.

Each genotype was evaluated for the following traits: Days until the first female flower anthesis, main branch length, fruit mass, number of fruits per plant, yield, fruit length, fruit width, pulp firmness, soluble solids content ('Brix), rind thickness, seed length, seed width, and seed mass.

Analyses of variance were performed for the data of each of the evaluated characters, following this model:

$$
Y_{i j}=\mu+T_{i}+B_{j}+e_{i j}
$$

Where: $Y_{i j}$ is the observation of the $i$-th treatment of the j-th block; $\mu$ is the effect of the overall mean; $T_{i}$ is the effect of the $i$-th treatment; $B_{j}$ is the effect of the $j$-th block; and $e_{i j}$ is the effect of the experimental error.

The effects of the general and specific combining abilities of the parents were estimated using the method proposed by Griffing (1956) for analysis of diallel with parents, F1 hybrids and F1 reciprocals, (Method I), considering the effect of treatments as fixed. The analysis of variance of the diallel was performed according to the scheme presented by Cruz et al. (2012) using the model:

$$
Y_{i}=\mu+g_{i}+g_{j}+s_{i j}+r_{i j}+\varepsilon_{i j}
$$

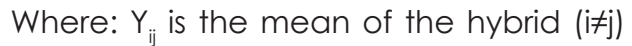
or of the parent ( $\mathrm{i}=\mathrm{j}) ; \mu$ is the overall mean of the diallel; $g_{i}$ and $g_{j}$ are the effects of the general combining ability of the i-th or the j-th parent; $s_{i j}$ is the effect of the specific combining ability for the cross between the $i$ and $j$ order parents; $r_{i j}$ is the reciprocal effect that measures the differences produced by parent $\mathrm{i}$ or $\mathrm{j}$ when used as a pollen donor or recipient, and $\varepsilon_{\mathrm{ij}}$ is the experimental error. The analyses were conducted with the aid of the GENES software (Cruz, 2013).

\section{Results and discussion}

Significant differences between the treatments were observed for all the traits evaluated, thus evincing the existence of genetic variability among the treatments (Table 2).

\begin{tabular}{|c|c|c|c|c|c|c|c|c|}
\hline \multirow{3}{*}{ Traits (2) } & \multirow{3}{*}{ Average } & \multirow{3}{*}{ Maximum } & \multirow{3}{*}{ Minimum } & \multirow{3}{*}{ CV (\%) } & \multicolumn{4}{|c|}{ Mean squares (1) } \\
\hline & & & & & $\mathrm{FV}$ & Blocks & Treatments & Residues \\
\hline & & & & & $\mathrm{DF}$ & 2 & 35 & 70 \\
\hline FFA (days) & 44.19 & 54.00 & 33.00 & 2.3 & & 0.528 & $27.417^{* *}$ & 1.061 \\
\hline$M B L(m)$ & 2.17 & 2.81 & 1.58 & 5.2 & & 0.026 & $3.648^{* *}$ & 0.013 \\
\hline FM (kg) & 5.20 & 8.22 & 2.15 & 14.0 & & 3.484 & $0.111^{* *}$ & 0.532 \\
\hline NF/P (unit) & 2.20 & 4.00 & 1.00 & 19.2 & & 0.210 & $0.516^{* *}$ & 0.178 \\
\hline YD (t/ha) & 45.29 & 91.61 & 16.24 & 21.7 & & 1693.105 & $273.211^{* *}$ & 96.507 \\
\hline $\mathrm{FL}(\mathrm{cm})$ & 27.80 & 39.17 & 19.17 & 4.8 & & 11.442 & $70.009 * *$ & 1.785 \\
\hline $\mathrm{FW}(\mathrm{cm})$ & 20.93 & 24.87 & 16.53 & 5.0 & & 10.864 & $5.829 * *$ & 1.098 \\
\hline PF (\%) & 453.42 & 926.30 & 256.46 & 12.2 & & 1624.712 & $45202.108^{* *}$ & 3063.016 \\
\hline SSC ('Brix) & 9.97 & 12.73 & 7.73 & 5.5 & & 1.769 & $1.958^{* *}$ & 0.296 \\
\hline ART (cm) & 0.98 & 1.27 & 0.58 & 6.0 & & 0.021 & $0.047^{* *}$ & 0.003 \\
\hline $\mathrm{SL}(\mathrm{mm})$ & 8.48 & 12.40 & 5.60 & 2.5 & & 0.107 & $9.481^{* *}$ & 0.046 \\
\hline $\mathrm{SW}(\mathrm{mm})$ & 5.31 & 8.05 & 3.50 & 2.8 & & 0.007 & $4.330^{* *}$ & 0.022 \\
\hline SM (mg) & 43.24 & 100.00 & 20.00 & 9.1 & & 28.704 & $1200.926^{* *}$ & 15.370 \\
\hline
\end{tabular}

Table 2. Summary of the analysis of variance of the cross between watermelon parents.

The coefficients of variation (CV) for most of the evaluated characters were low, lower than $10.0 \%$, which evidenced high experimental precision and homogeneity within the plots of parents and hybrids (Table 2). The characters of fruit mass, number of fruits per plant, and pulp firmness exhibited medium coefficient of variation, lower than $20.0 \%$, which demonstrates 
good experimental precision. Only the yield character showed a high CV value. Tavares et al. (2018), when evaluating this same character in watermelon genotypes, obtained a CV higher than $20 \%$, and a similar result was obtained by Nascimento et al. (2018). These results show that because it is a polygenic trait and with a strong environmental influence, this value can be considered normal.

Significant differences were observed for the effects of the general combining ability (GCA) as well as the effects of the specific combining ability (SCA), for all the characters, except for the soluble solids content for SCA (Table 3), which showed that the additive and non-additive gene interaction occurred simultaneously in the control of the traits evaluated. These results are partially in agreement with those reported by Bahari et al. (2012), who worked with four pure lines of watermelon. However, in the present study the analysis of quadratic components (Table 3) showed that the control of the characters 'days before female flower anthesis', number of fruits per plant, yield, and seed mass was due to the prevalence of non-additive effects over additive ones; however, the opposite occurred for fruit mass, length and width, pulp firmness, rind thickness, seed length and seed width. For the main branch length, in turn, the quadratic components for GCA and SCA were the same, which showed simultaneous additive and nonadditive action controlling the trait.

Table 3. Mean squares and quadratic components of the general and specific combining ability and reciprocal effects of watermelon characters.

\begin{tabular}{|c|c|c|c|c|c|c|c|}
\hline \multirow{3}{*}{ Traits (2) } & \multicolumn{4}{|c|}{ Mean squares (1) } & \multicolumn{3}{|c|}{ Quadratic components } \\
\hline & GCA & SCA & RE & Residue & & & \\
\hline & DF & 15 & 15 & 70 & $G C A$ & SCA & RE \\
\hline FFA (days) & $98.767^{*}$ & $14.817^{*}$ & 16.233* & 1.061 & 2.714 & 4.585 & 2.529 \\
\hline MBL (m) & $0.160 *$ & $0.025^{* *}$ & $0.179 *$ & 0.013 & 0.004 & 0.004 & 0.028 \\
\hline $\mathrm{FM}(\mathrm{kg})$ & $19.840^{*}$ & $0.978^{* *}$ & $0.919 \mathrm{~ns}$ & 0.532 & 0.536 & 0.149 & 0.065 \\
\hline NF/P (unit) & $0.445^{* *}$ & $0.944^{*}$ & $0.111 \mathrm{~ns}$ & 0.178 & 0.007 & 0.255 & -0.011 \\
\hline YD (t/ha) & $790.756^{*}$ & $230.644^{*}$ & $143.263 \mathrm{~ns}$ & 96.507 & 19.285 & 44.712 & 7.793 \\
\hline $\mathrm{FL}(\mathrm{cm})$ & $457.707^{*}$ & $7.709^{*}$ & $3.078 \mathrm{~ns}$ & 1.785 & 12.665 & 1.975 & 0.215 \\
\hline $\mathrm{FW}(\mathrm{cm})$ & $27.118^{*}$ & $2.613^{*}$ & $1.949 *$ & 1.098 & 0.723 & 0.505 & 0.142 \\
\hline PF (\%) & $211106.588 *$ & $11402.250 *$ & $23700.473^{*}$ & 3063.016 & 5778.988 & 2779.745 & 3439.576 \\
\hline SSC ('Brix) & $9.025^{*}$ & $0.512 \mathrm{~ns}$ & 1.049* & 0.296 & 0.242 & 0.072 & 0.126 \\
\hline ART (cm) & $0.271^{*}$ & $0.012^{*}$ & $0.006 *$ & 0.003 & 0.007 & 0.003 & 0.000 \\
\hline $\mathrm{SL}(\mathrm{mm})$ & $51.332 *$ & $3.965^{*}$ & $1.047^{*}$ & 0.046 & 1.425 & 1.306 & 0.167 \\
\hline $\mathrm{sW}(\mathrm{mm})$ & $23.391^{*}$ & 1.938* & $0.368 *$ & 0.022 & 0.649 & 0.639 & 0.058 \\
\hline $\mathrm{SM}$ (mg) & 6198.519* & 597.099* & 138.889* & 15.370 & 171.754 & 193.909 & 20.586 \\
\hline
\end{tabular}

Regarding the SCA, no significant differences were found for soluble solids content, indicating that the GCA for this character, although negative in some parents, when combined, allelic complementation occurred, which favored the increase of the soluble solids content in the hybrid combinations thus pointing to the action of additive effects controlling the trait. These results differ from those presented by Barros et al. (2011) and Gvozdanovic-Varga et al. (2011), in which the occurrence of non-additive effects controlling the soluble solids content was reported. Such a contrast can be explained by the genetic difference between the genotypes studied or due to the interaction genotype $x$ environment.

There were significant reciprocal effects (RE) at a 5\% significance level among the parents in relation to days before female flower anthesis, main branch length, fruit width, pulp firmness, soluble solids content, rind thickness, seed length, seed width, and seed mass (Table 3), which allowed suggesting that for the genetic control of these traits, extrachromosomal inheritance or maternal effects were involved. Ferreira et al. (2002) corroborate similar results, where significant differences were found for male flower anthesis and soluble solids content, except for the number of fruits per plant, which did not show reciprocal effects. The genetic interaction of RE 
is of great importance for breeding programs aimed at the development of hybrids because it allows determining which parents should be used either as pollen donors or pollen recipients.

Table 4 shows the estimates of the general combining ability of the parents. Genotype 'JNY' (1) showed negative values for the character 'days before female flower anthesis', fruit mass, yield, fruit length, soluble solids content, rind thickness, seed length and seed mass, and positive effects for number of fruits per plant, fruit width, and pulp firmness, suggesting that the parent when recombined contributed to the development of early, productive hybrids and fruits with lower weight and shorter length, and smaller-sized seeds, showing potential for use in genetic breeding programs aimed at the development of genotypes with smaller fruits and with smaller seeds.

Parent 'ORA' (2) showed negative effects for the character 'days before the female flower anthesis', number of fruits per plant, fruit length, pulp firmness, soluble solids content, and positive effects for fruit mass, yield, fruit width, rind thickness, seed length, seed width and seed mass, indicating the parent's contribution to obtain genotypes with heavier productive fruits, with a thicker rind, and larger and heavier seeds.

Table 4. Estimates of the general combining ability effects on watermelon parents

\begin{tabular}{|c|c|c|c|c|c|c|c|c|c|c|c|c|}
\hline \multirow{2}{*}{$\begin{array}{l}\text { General } \\
\text { combining } \\
\text { ability }{ }^{(2)}\end{array}$} & \multicolumn{12}{|c|}{ Traits (1) } \\
\hline & $\begin{array}{l}\text { FFA } \\
\text { (days) }\end{array}$ & $\begin{array}{cc}M B L & F M \\
(\mathrm{~m}) & (\mathrm{kg})\end{array}$ & $\begin{array}{l}\text { NF/P } \\
\text { (unit) }\end{array}$ & $\begin{array}{l}\text { YD } \\
\text { (t/ha) }\end{array}$ & $\begin{array}{c}\mathrm{FL} \\
(\mathrm{cm})\end{array}$ & $\begin{array}{l}\mathrm{FW} \\
(\mathrm{cm})\end{array}$ & $\begin{array}{l}\text { PF } \\
(\%)\end{array}$ & $\begin{array}{l}\text { SSC } \\
\text { ('Brix) }\end{array}$ & $\begin{array}{l}\text { ART } \\
(\mathrm{cm})\end{array}$ & $\begin{array}{c}\mathrm{SL} \\
(\mathrm{mm})\end{array}$ & $\begin{array}{c}\text { SW } \\
(\mathrm{mm})\end{array}$ & $\begin{array}{l}\text { SM } \\
\text { (mg) }\end{array}$ \\
\hline 'JNY' (1) & -0.222 & $-0.049-0.599$ & 0.097 & -0.001 & -2.680 & 0.118 & 132.051 & -0.104 & 0.001 & -1.921 & -1.305 & -18.796 \\
\hline 'ORA' (2) & -0.139 & -0.0100 .124 & -0.114 & 2.499 & -0.801 & 0.941 & -3.624 & -0.255 & 0.038 & 1.233 & 0.799 & 13.981 \\
\hline 'KOD' (3) & 0.389 & $-0.083-1.014$ & 0.089 & -8.037 & -3.014 & -1.387 & -37.760 & -0.299 & -0.157 & -0.855 & -0.546 & -9.074 \\
\hline 'SOL' (4) & -2.861 & $0.095-0.069$ & 0.061 & -1.083 & -1.671 & 0.857 & -91.907 & 0.254 & -0.028 & 0.305 & 0.155 & 1.759 \\
\hline 'CHG' (5) & 0.611 & -0.0131 .038 & -0.164 & 6.130 & 6.377 & -0.449 & -30.972 & -0.484 & 0.072 & 1.023 & 0.749 & 14.815 \\
\hline 'PEA' (6) & 2.222 & 0.0610 .520 & 0.031 & 0.493 & 1.789 & -0.080 & 32.213 & 0.888 & 0.076 & 0.215 & 0.147 & -2.685 \\
\hline DP (ĝi) & 0.157 & 0.0170 .111 & 0.064 & 1.495 & 0.203 & 0.159 & 8.420 & 0.083 & 0.009 & 0.033 & 0.023 & 0.596 \\
\hline
\end{tabular}

Parent 'KOD' (3) showed a positive GCA value for number of fruits per plant, and negative values for fruit mass, fruit length, fruit width, rind thickness, seed length, seed width and seed mass, suggesting that this parent contributes to the development of hybrids with lower fruit mass and smaller size, with thinner rind, smaller seeds and less mass, evidencing their potential for use in breeding programs that aim to obtain cultivars that meet the consumers' demand for smaller fruits.

Parent 'SOL' (4) presented negative GCA effects for 'days before for female flower anthesis', fruit mass, yield, fruit length, pulp firmness and rind thickness, and positive values for number of fruits per plant, fruit width, soluble solids content, seed length, seed width and seed mass, pointing to the contribution of this parent to the development of hybrids with early, prolific, less productive plants with lighter fruits of shorter length, greater width and with soft pulp, thinner rind and larger and heavier seeds.
This parent can be used in breeding programs for the development of intermediate fruit size genotypes.

Parent 'CHG' (5) presented positive GCA effect for 'days before for female flower anthesis', fruit mass, yield, fruit length, rind thickness, seed length, seed width and seed mass, and negative effects for number of fruits per plant, fruit width, pulp firmness and soluble solids content, which indicated the contribution of this parent in the development of late hybrids with greater fruit mass, with a reduced number of fruits per plant, greater yield, longer fruits but with reduced width, soft pulp, less sweet fruits, thicker rind, larger and heavier seeds. Souza et al. (2013), when studying the combining ability of that same genotype, found results partially divergent from those found in the present study, as genotype 'CHG' (5) showed a positive general combining ability for fruit width and soluble solids content. Therefore, the authors suggested the use of this genotype in breeding programs for the development of large 
fruits, given the expanded demand for sliced watermelon in supermarkets, open fairs and greengrocers.

Parent PEA (6) showed positive GCA values (Table 4) for days before female flower anthesis, fruit mass, number of fruits per plant, yield, fruit length, pulp firmness, soluble solids content, rind thickness, seed length, seed width and seed mass, and negative values for fruit width, indicating that this genotype, when recombined, contributed to the development of late hybrids, with extensive, prolific, long branch length, with great fruit mass, higher yield, with firm pulp, sweet fruits and larger seeds.

According to Cruz \& Vencovsky (1989), the most promising hybrid combinations are those with high SCA effects (positive or negative, depending on the character under study) resulting from crosses between divergent parents, where at least one of them shows a high GCA. However, according to Ferreira et al. (2002), two high GCA parents when crossed will not always originate the best diallel hybrid. Thus, the opposite can also occur, where two parents with negative GCA values, when combined, may originate hybrids with positive SCA values, as reported in the present study.

Based on the specific combining ability (Table 5), hybrids ' $1 \times 5,1 \times 6,2 \times 3,2 \times 4,3 \times 5,4 \times 6$ and $5 \times 6$ ' were noted as the most promising ones in terms of precocity; and the combinations ' $1 \times 2$, $1 \times 6,2 \times 3,2 \times 4,3 \times 4,3 \times 6,4 \times 5,4 \times 6$ and $5 \times 6$ ' in terms of fruits with higher mass, whereas ' $1 \times 3,1 \times 4,1 \times 5$, $2 \times 5,2 \times 6$ and $3 \times 5$ ' in terms of lower fruit mass; the combinations ' $1 \times 3,1 \times 4,1 \times 6,2 \times 3,2 \times 4$ and $2 \times 5$ ' were the most promising ones for prolificity; in terms of yield, hybrids ' $1 \times 2,1 \times 4,1 \times 6,2 \times 3,2 \times 4,3 \times 5$, $3 \times 6,4 \times 6$ and $5 \times 6$ ' stood out; for smaller fruit size (fruit length and width), the combinations " $1 \times 3$ and $2 \times 6$ ' were prominent; the combinations ' $1 \times 2$, $1 \times 4,1 \times 5,2 \times 3,4 \times 6$ and 5x6' for soft fruit pulp; for the highest concentration of soluble solids, hybrids ' $1 \times 6,2 \times 3,2 \times 4,2 \times 5,3 \times 5,4 \times 5$ and $4 \times 6$ ' were noted; as for rind thickness the combinations ' $1 \times 2,1 \times 4$, $1 \times 6,2 \times 3,2 \times 4,2 \times 5,3 \times 4,3 \times 6$ and $4 \times 5$ ' were the most promising ones; for seed size (length, width) and

Table 5. Estimates of the specific combining ability effects on watermelon hybrids

\begin{tabular}{|c|c|c|c|c|c|c|c|c|c|c|c|c|c|}
\hline \multirow[b]{2}{*}{ Hybrids ${ }^{(1)}$} & \multicolumn{13}{|c|}{ Traits analyzed (2) } \\
\hline & $\begin{array}{c}\text { FFA } \\
\text { (days) }\end{array}$ & $\begin{array}{l}\text { MBL } \\
(\mathrm{m})\end{array}$ & $\begin{array}{l}\text { FM } \\
(\mathrm{kg})\end{array}$ & $\begin{array}{l}\text { NF/P } \\
\text { (unit) }\end{array}$ & $\begin{array}{c}\text { YD } \\
\text { (t/ha) }\end{array}$ & $\begin{array}{c}\mathrm{FL} \\
(\mathrm{cm})\end{array}$ & $\begin{array}{c}\mathrm{FW} \\
(\mathrm{cm})\end{array}$ & $\begin{array}{l}\text { PF } \\
\text { (\%) }\end{array}$ & $\begin{array}{c}\text { SSC } \\
\text { ('Brix) }\end{array}$ & $\begin{array}{l}\text { ART } \\
(\mathrm{cm})\end{array}$ & $\begin{array}{c}\mathrm{SL} \\
(\mathrm{mm})\end{array}$ & $\begin{array}{c}\text { SW } \\
(\mathrm{mm})\end{array}$ & $\begin{array}{c}\text { SM } \\
\text { (mg) }\end{array}$ \\
\hline $1 \times 1$ & -0.750 & -0.008 & 0.350 & 0.003 & -7.002 & 0.396 & -0.385 & 47.677 & 0.165 & 0.022 & 1.248 & 0.852 & 14.352 \\
\hline $1 \times 2$ & 0.000 & 0.003 & 0.080 & -0.153 & 2.008 & 0.037 & 0.006 & -61.707 & $7-0.242$ & 0.004 & -0.768 & -0.618 & -8.426 \\
\hline $1 \times 3$ & 0.972 & -0.060 & -0.700 & 0.011 & -6.135 & -1.242 & -1.295 & 13.976 & -0.247 & -0.051 & 0.225 & 0.183 & 4.630 \\
\hline $1 \times 4$ & 1.556 & -0.066 & -0.112 & 0.006 & 1.587 & 0.867 & 0.104 & -20.217 & $7-0.006$ & 0.002 & 0.199 & 0.206 & 0.463 \\
\hline $1 \times 5$ & -0.417 & 0.052 & -0.313 & -0.186 & -1.643 & -0.208 & 0.632 & -0.866 & -0.005 & -0.010 & -0.801 & -0.543 & -10.926 \\
\hline $1 \times 6$ & -1.361 & 0.079 & 0.694 & 0.319 & 11.186 & 0.150 & 0.938 & 21.136 & 0.336 & 0.033 & -0.102 & -0.081 & -0.093 \\
\hline $2 \times 2$ & -0.250 & -0.109 & -0.320 & -0.375 & -6.283 & -0.323 & -0.469 & 62.018 & -0.566 & -0.027 & 0.989 & 0.796 & 12.130 \\
\hline $2 \times 3$ & -1.444 & 0.090 & 0.566 & 0.172 & 6.980 & 1.232 & 1.0 & -72 & 0.369 & 0.004 & -0.698 & -0. & -4 \\
\hline $2 \times 4$ & -0.028 & 0.000 & 0.257 & 0.250 & 2.873 & 0.136 & -0.112 & 6.929 & 0.234 & 0.022 & -0.283 & -0.174 & 15 \\
\hline $2 \times 5$ & 0.833 & 0.060 & -0.157 & 0.292 & -2.500 & 0.346 & -0.285 & 23.919 & 0.211 & 0.007 & 1.275 & 0.781 & 11.296 \\
\hline $2 \times 6$ & 0.889 & -0.044 & -0.426 & -0.186 & -3.0 & -1.4 & -0 & 41 & -0. & -0 . & -0 . & -0 . & 70 \\
\hline $3 \times 3$ & -1.639 & 0.025 & -0.124 & 0.553 & -4.518 & -1.9 & -0.338 & 15.495 & 0.274 & -0.082 & 1.032 & 0.714 & 8.241 \\
\hline $3 \times 4$ & 0.778 & -0.031 & 0.137 & -0.586 & -0.451 & -0.1 & 0.298 & 13.529 & -0.364 & 0.038 & 0.322 & 0.119 & 2.407 \\
\hline $3 \times 5$ & -0.694 & -0.046 & -0.038 & -0.061 & 1.387 & 1.184 & 0.044 & 12 & 0.301 & -0.010 & -1.576 & -1.090 & -18.981 \\
\hline $3 \times 6$ & 2.028 & 0.022 & 0.159 & -0.089 & 2.738 & 0.949 & 0.202 & 16.385 & -0.333 & 0.101 & 0.695 & 0.493 & 8.519 \\
\hline $4 \times 4$ & -4.806 & 0.096 & -0.417 & 1.008 & -7.398 & -0.505 & -0.896 & 63.009 & -0.225 & -0.059 & -0.274 & 0.010 & 3.241 \\
\hline $4 \times 5$ & 2.722 & -0.064 & 0.083 & -0.067 & -2.265 & 0.048 & -0.080 & 2.725 & 0.035 & 0.011 & -0.172 & -0.147 & -4.815 \\
\hline $4 \times 6$ & -0.222 & 0.064 & 0.052 & -0.611 & 5.654 & -0.397 & 0.686 & -65.974 & 0.326 & -0.014 & 0.207 & -0.015 & 1.019 \\
\hline $5 \times 5$ & -1.750 & -0.020 & 0.051 & 0.325 & 1.929 & -3.129 & 0.402 & 26.329 & -0.445 & 0.068 & 1.479 & 1.176 & 27.130 \\
\hline $5 \times 6$ & -0.694 & 0.017 & 0.373 & -0.303 & 3.093 & 1.760 & -0.711 & -65 & $3-0.096$ & -0.066 & -0.205 & -0.177 & -3.704 \\
\hline $6 \times 6$ & -0.639 & -0.138 & -0.852 & 0.869 & -19.594 & $4-1.035$ & -0.885 & 52.334 & -0.227 & -0.043 & $3-0.081$ & 0.146 & 2.130 \\
\hline$\overline{S D}\left(\hat{S}_{\mathrm{iij}}-\hat{S}_{\mathrm{ij}}\right)^{(3)}$ & 0.687 & 0.076 & 0.486 & 0.281 & 6.549 & 0.891 & 0.699 & 36.896 & 0.363 & 0.039 & 0.143 & 0.099 & 2.614 \\
\hline $\operatorname{SD}\left(\hat{s}_{i j}-\hat{s}_{i k}\right)$ & 0.543 & 0.066 & 0.421 & 0.172 & 5.672 & 0.771 & 0.605 & 31.953 & 0.314 & 0.034 & 0.124 & 0.086 & 2.264 \\
\hline $\operatorname{SD}\left(\hat{s}_{i j}-\hat{s}_{k l}\right)$ & 0.486 & 0.060 & 0.384 & 0.222 & 5.178 & 0.704 & 0.552 & 29.169 & 0.287 & 0.031 & 0.113 & 0.078 & 2.066 \\
\hline
\end{tabular}


seed mass the combinations ' $1 \times 2,1 \times 5,1 \times 6,2 \times 3$, $2 \times 4,2 \times 6,3 \times 5,4 \times 5$ and $5 \times 6$ ' stood out in terms of smaller sized seeds and seed mass because the effect of the SCA was in agreement with the GCA of their parents, for most of the characters evaluated.

In relation to all the characters studied, some hybrid combinations, as well as their reciprocal ones, showed negative and positive values or vice versa, which indicates the action of reciprocal effects (Ferreira et al., 2002). Based on the reciprocal effects of the characters 'days before female flower anthesis', fruit mass, number of fruits per plant, yield, pulp firmness, soluble solids content, rind thickness, seed length, seed width and seed mass (Table 6), it was found that 'JNY' (1), when crossed with parents 'ORA' (2), 'KOD' (3), 'SOL' (4), 'CHG' (5) and 'PEA' (6), should be used as a pollen recipient, because in this case greater increases were observed in terms of precocity, prolificacy, yield and reduction of seed size; genotype 'ORA' (2), when crossed with 'KOD' (3), 'SOL' (4), 'CHG' (5) and 'PEA' (6), should be used as a pollen recipient owing to its increased fruit mass, prolificacy, yield, firmer pulp, sweeter fruits, with thicker rind and small seeds; the genotypes 'SOL' (4), 'CHG' (5) and 'PEA' (6) when crossed with 'KOD' (3), should be used as a pollen donor due to higher reduction of fruit mass, increased prolificacy, sweet fruits with firmer pulp and smaller seeds; genotype 'SOL' (4), when crossed with 'CHG' (5) and 'PEA' (6), should be used as a pollen recipient for its contribution to precocity, prolificity, sweet fruits with firmer pulp and smaller seeds; in the cross between genotypes 'PEA' (6) and 'CHG' (5), the latter should be used as a pollen recipient, since the reciprocal effects demonstrate the superiority of the hybrids obtained.

Table 6. Estimates of the reciprocal effects on watermelon hybrids

\begin{tabular}{|c|c|c|c|c|c|c|c|c|c|c|c|c|c|}
\hline \multirow[b]{2}{*}{ Hybrids ${ }^{(1)}$} & \multicolumn{13}{|c|}{ Traits analyzed (2) } \\
\hline & $\begin{array}{c}\text { FFA } \\
\text { (days) }\end{array}$ & $\begin{array}{l}\text { MBL } \\
(\mathrm{m})\end{array}$ & $\begin{array}{l}\mathrm{FM} \\
(\mathrm{kg})\end{array}$ & $\begin{array}{l}\mathrm{NF} / \mathrm{P} \\
\text { (unit) }\end{array}$ & $\begin{array}{c}\text { YD } \\
(t / h a)\end{array}$ & $\mathrm{FL}$ & $\begin{array}{l}\mathrm{FW} \\
(\mathrm{cm})\end{array}$ & $\begin{array}{l}\mathrm{PF} \\
(\%)\end{array}$ & $\begin{array}{c}\text { SSC } \\
\text { ('Brix) }\end{array}$ & $\begin{array}{l}\text { ART } \\
(\mathrm{cm})\end{array}$ & $\mathrm{SL}(\mathrm{mm})$ & $\begin{array}{c}\text { SW } \\
(\mathrm{mm})\end{array}$ & $\begin{array}{c}\text { SM } \\
\text { (mg) }\end{array}$ \\
\hline $2 \times 1$ & 0.833 & -0.327 & -0.639 & 0.100 & -8.317 & -1.247 & -0.828 & 55.470 & -0.185 & 0.027 & -0.102 & -0.035 & 0.000 \\
\hline $3 \times 1$ & 1.333 & -0.272 & 0.338 & -0.133 & 3.198 & 0.665 & 1.132 & -148.225 & -0.523 & -0.050 & 117 & -0.063 & 0.000 \\
\hline $4 \times 1$ & 0.667 & -0.230 & -0.639 & -0.033 & -6.453 & 0.360 & -0.162 & -74.017 & 0.307 & -0.012 & 0.060 & 0.155 & 3.333 \\
\hline $5 \times 1$ & 1.167 & -0.243 & 0.178 & 0.250 & 2.497 & 0.573 & 1.260 & 120.884 & -1.120 & 0.083 & -0.092 & -0.160 & -1.667 \\
\hline $6 \times 1$ & 0.167 & 0.023 & -0.088 & 0.050 & -8.588 & 0.217 & 0.262 & 67.005 & 0.193 & 0.010 & & -0.080 & -1.667 \\
\hline $3 \times 2$ & -0.667 & 0.083 & 0.268 & 0.183 & 1.273 & 0.535 & -0.003 & -7.354 & -0.135 & -0.050 & 1.398 & 0.843 & 13.333 \\
\hline $4 \times 2$ & -1.167 & 0.012 & -0.115 & 0.000 & -2.240 & -0.015 & -0.128 & -28.766 & -0.007 & 0.000 & 0.167 & 0.080 & -3.333 \\
\hline $5 \times 2$ & 1.167 & -0.043 & -0.197 & -0.117 & -1.520 & 0.900 & 0.193 & 8.054 & 0.402 & 0.015 & -0.223 & -0.115 & -6.667 \\
\hline $6 \times 2$ & 1.500 & 0.090 & 0.143 & -0.200 & -2.640 & -0.305 & 0.007 & -9.752 & 0.365 & -0.005 & 0.112 & -0.078 & 3.333 \\
\hline $4 \times 3$ & 0.500 & -0.015 & -0.450 & -0.167 & -2.353 & -0.067 & 0.273 & 12.689 & 0.322 & 0.015 & -0.717 & -0.337 & -8.333 \\
\hline $5 \times 3$ & 3.500 & -0.272 & -0.425 & 0.067 & -5.725 & -0.838 & -0.517 & 22.370 & 0.468 & 0.000 & -0.027 & -0.025 & 0.000 \\
\hline $6 \times 3$ & 3.167 & -0.090 & -0.639 & -0.033 & -8.258 & -1.408 & -0.490 & 49.253 & -0.287 & -0.025 & -0.043 & -0.073 & 0.000 \\
\hline $5 \times 4$ & 2.333 & -0.095 & -0.214 & 0.033 & -2.653 & -0.485 & -0.323 & 64.715 & -0.245 & -0.013 & -0.023 & -0.010 & 1.667 \\
\hline $6 \times 4$ & 1.667 & 0.217 & 0.571 & 0.183 & 3.092 & -0.632 & 0.695 & 5.206 & -0.075 & 0.005 & 0.105 & 0.040 & 3.333 \\
\hline $6 \times 5$ & 0.333 & -0.015 & -0.148 & 0.167 & 4.253 & 0.823 & -0.018 & -35.758 & 0.382 & 0.033 & -0.035 & 0.015 & -1.667 \\
\hline$S D\left(r \wedge \wedge_{i j}\right)^{(3)}$ & 0.421 & 0.054 & 0.344 & 0.199 & 4.631 & 0.630 & 0.494 & 26.090 & 0.257 & 0.027 & 0.101 & 0.070 & 1.848 \\
\hline$S D\left(r \wedge_{i j}-r^{\prime} \wedge_{k}\right)$ & 0.595 & 0.066 & 0.421 & 0.244 & 5.672 & 0.771 & 0.605 & 31.953 & 0.314 & 0.034 & 0.124 & 0.086 & 2.264 \\
\hline
\end{tabular}

\section{Conclusions}

1 - In terms of general combining ability, genotypes 'JNY' (1) and 'KOD' (3) are evidenced as being the most promising ones to obtain hybrids with smaller fruit size and smaller seeds.

2 - Genotypes 'ORA' (2) and 'CGH' (5) can be used to produce hybrids with greater fruit mass.

3 - The reciprocal effects indicated that genotypes 'KOD' (3) and 'JNY' (1) should be used as a pollen recipient and a pollen donor, respectively, for the development of genotypes with smaller fruit size and smaller seeds.

4- In terms of specific combining ability, combinations 'ORA' (2) x 'PEA' (6); 'ORA' (2) x 'JNY' (1); 'CHG' (5) x 'KOD' (3); 'PEA' (6) x 'KOD' (3) and 'CHG' (5) x 'SOL' (4) stand out for their potential for the development of genotypes with 
the smallest fruit size and smallest seeds.

\section{Acknowledgements}

We thank the Brazilian National Council for Scientific and Technological Development (CNPq) for granting a scholarship to the postgraduate student. We also thank colleagues Taise Oliveira Passos and Ronny Elisson Ribeiro Cavalcante for their friendship, care and help with the evaluations.

\section{References}

Adjoumani, K., Kouonon, L.C., Koffi, G.K., Bony, B.S., Brou, K.F., Akaffou, D. S.; Sie, R. S. 2016. Analysis on genetic variability and heritability of fruit characters in Citrullus lanatus (Thunb.) Matsumura and Nakai (Cucurbitaceae) cultivars. Journal of Animal \&Plant Sciences 28: 4340-4355.

Bahari, M., Rafii, M.Y., Saleh, G.B., Latif, M.A. 2012. Combining Ability Analysis in Complete Diallel Cross of Watermelon (Citrullus lanatus (Thunb.) Matsum. \& Nakai). The Scientific World Journal 2012: 1-6.

Barreto, R.R., Scapim, C.A., Amaral Júnior, A.T., Rodovalho, M.A., Vieira, R.A., Schuelter, A.R. 2012. Avaliação da capacidade de combinação de famílias S2 de milho pipoca por meio de diferentes testadores. Ciências Agrárias 33: 873890.

Barros, A.K.A., Nunes, G.H.S., Queiróz, M.A.Q., Pereira, E.W.L., Costa Filho, J.H. 2011. Diallel analysis of yield and quality traits of melon fruits. Crop Breeding and Applied Biotechnology 11: 313-319.

Carvalho, A.D.F., Silva, G.O., Pereira, R.B., Pinheiro, J.B., Vieira, J.V. 2014. Capacidade combinatória em cenoura para componentes de produção e tolerância à queima-das-folhas. Horticultura Brasileira 32: 190-193.

Cruz, C.D. 2013. GENES: a software package for analysis in experimental statistics and quantitative genetics. Acta Scientiarum 35: 271-276.

Cruz, C.D., Regazzi, A.J., Carneiro, P.C.S. 2012. Modelos biométricos aplicados ao melhoramento genético. UFV: Imprensa Universitária, Viçosa, Brasil $514 \mathrm{p}$.

Ferreira, M.A.J.F., Braz, L.T., Queiroz, M.A., Crurata-Masca, M.G.C. 2002. Capacidade de combinação em sete populações de melancia. Pesquisa Agropecuária Brasileira 37: 963-970.

Gama, F.C., Viza, R. 2008. Uso culinário. In: Neto, C.R., Teixeira, C.A.D., Fernandes, C.F., Gama, F.C., Souza, F.F., Franderson, J.E., Costa, J.N.M.,
Queiróz, M.A., Dias, R.C., Viza, R., Holanda Filho, Z.F. Cultivo da melancia em Rondônia. Embrapa Informação Tecnológica, Brasília, Brasil, p. 96-103.

Gama, R.N.C, Santos, C.A.F., Dias, R.C.S. Genetic variability of watermelon accessions based on microsatellite marker. Genetics and Molecular Research 12: 747-754

Gama, R.N.C.S., Santos, C.A.F., Dias, R.C.S., Alves, J.C.S.F., Nogueira, T.O. 2015. Microsatellite markers linked to the locus of the watermelon fruit stripe pattern. Genetics and Molecular Research 14: 269-276.

Gbatto, A.A., Koff, K.K., Fouha Bi, N.D., Doubi Bi, S.T., Tro, H.H., Baudoi, J.P., Zoro Bi, I.A. Morphological diversity in oleaginous watermelon (Citrullus mucosospermus) from the Nangui Abrogoua University germplasm collection. African Journal of Biotechnology 15: 917-929

Griffing, B.A. 1956. Concepto of general and specific combining ability in relation to diallel crossing systems. Australian Journal of Biological Sciences 9: 463-493.

Gvozdanovic-Varga, J.; Vasic, M.; Milic, D.; Cervenski, J. 2011. Diallel cross analysis for fruit traits in watermelon. Genetika 43: 163-174.

IBGE. Instituto Brasileiro de geografia e Estatística. Produção agrícola municipal: culturas temporárias e permanentes/SIDRA. 2016. http://biblioteca.ibge.gov.br/index.php/ atalogo? view=detalhes\&id=766<Acess on 02 jun. 2017>

Mendes, A.M.S. Faria, C.M.B. Silva, D.J. In: Dias, R. de C. S. et al. (Eds.). Sistema de produção de melancia. Petrolina: Embrapa Semiárido, 2010. Available at: <https://sistemasdeproducao. cnptia.embrapa.br/FontesHTML/Melancia/ SistemaProducaoMelancia/adubacao.htm>. Acesso em: 20 maio. 2017.

Nantoumé, A.D., Traoré, S., Christiansen, J.L., Andersen, S.B., Ensen, B.D. 2012. Traditional uses and cultivation of indigenous watermelons (Citrullus lanatus) in Mali. International Journal of Biodiversity and Conservation 4: 461-471.

Nantoumé, A.D., Andersen, S.B., Jensen, B.D. 2013. Genetic differentiation of watermelon landrace types in Mali revealed by microsatellite (SSR) markers. African Journal of Biotechnology 12: 5513-5521

Nascimento, T.L. do, Souza, F.F., Dias, R.C.S, Silva, E.F. 2018. Agronomic characterization and heterosis in watermelon genotypes. Pesquisa Agropecuária Tropical 48: 170-177.

Oliveira, R.A., Nunes, G.H.S., Oliveira, D.A., Guimarães, I.P. 2008. Divergência genética entre 
acessos de melancia coletados no Estado do Rio Grande do Norte. Revista Brasileira de Ciências Agrárias 3: 213-217.

Piovesan, J.I. 2012. Capacidade combinatória e ação gênica em genótipos de melancia. 52 f. (Dissertação de Mestrado) Universidade Federal do Tocantins, Tocantins, Brasil.

Ramos, A.R.P., Dias, R.C.S., Aragão, C.A., Batista, P.F., Pires, M.M.L. 2012. Desempenho de genótipos de melancia de frutos pequenos em diversas densidades de plantio. Horticultura Brasileira 30: 333-338.

Rocha, F., Stinghen, J.C., Gemeli, M.S., Coimba, J.L.M., Guidolin, A.F. 2014. Análise dialélica como ferramenta na seleção de genitores em feijão. Revista Ciência Agronômica 45: 78-81

Santos, R.L., Pavan, M.A., Silva, N., Gioria, R., Souza Neto, I.L. Estimativas de capacidades de combinação em cebola para resistência a raíz rosada e caracteres agronômicos. Summa Phytopathol 41: 133-137.

Sapovadiya, M.H., Mehta, D.R., Dhaduk, H.L., Babariya, C.A. 2014. Combining ability in watermelon (Citrullus lanatus (Thumb.) Mansf.). Eletrocnic Journal of Plant Breeding 5: 327-330.

Singh, N.P., Dadwadia, G., Annapurna, G. 2009. Analysis of heterosis and combining ability status among diallel set of hybrids for yield and quality traits in watermelon (Citrullus lanatus Thunb). Vegetation Science 36: 323-326.

Souza, F.F. 2008. Cultivares. In: Neto, C.R., Teixeira, C.A.D., Fernandes, C.F., Gama, F.C., Souza, F.F., Franderson, J.E., Costa, J.N.M., Queiróz, M.A., Dias, R.C., Viza, R., Holanda Filho, Z.F. Cultivo da melancia em Rondônia. Embrapa Informação Tecnológica, Brasília, Brasil, p. 34-44.

Souza, F.F., Dias, R.C.S., Queiróz, M.A. 2013. Capacidade de combinação de linhagens avançadas e cultivares comerciais de melancia. Horticultura Brasileira 31: 595-601.

Tavares, A.T., Vaz, J.C., Coelho, R.S., Lopes, D.A. da S., Alves, F.Q.G., Nascimento, I.R. 2018. Aptidão agronômica de genótipos de melancia no sul do estado do Tocantins. Agropecuária Científica no Semiárido 14: 59-64. 